\title{
Children Motor Development with Authoritarian Parenting During the Industrial Revolution Era 4.0
}

\author{
Gunarti Dwi Lestari \\ Department of Non-Formal Education \\ Universitas Negeri Surabaya, Indonesia \\ gunartilestari@unesa.ac.id
}

\author{
Kartika Rinakit Adhe \\ Department of Early Childhood Education \\ Universitas Negeri Surabaya, Indonesia \\ kartikaadhe@unesa.ac.id
}

\author{
Muchamad Arif Al Ardha \\ Department of Physical Education \\ Universitas Negeri Surabaya, Indonesia \\ muchamadalardha@unesa.ac.id
}

\begin{abstract}
Motor development is not an issue on the impact of parenting problems. Survey research has the aim to determine the development of children's movements in the industrial revolution era 4.0 with authoritarian parenting. This research method is to use a type of quantitative research with survey methods. The target of this study is, children aged 4-5 years in Central Surabaya as a population. Samples from the population there are five schools. Data obtained and collected using observation techniques, questionnaire techniques, and documentation techniques. The results showed that parents in Central Surabaya who adopted an authoritarian parenting had the difference in results in the locomotor development of children. The survey results show that the development of children's movements for the ability to walk score is 3.7; running score is 3.97; jumping score is 3.68; and walking backward score is 3.83. From these results it shows the difference between a single developmental motion, there is no dominant or worse.
\end{abstract}

Keywords: authoritarian parenting; child motor development

\section{INTRODUCTION}

Motor development is an effort to improve the ability to move, so that development becomes more complex [1]. In the 4.0 industrial revolution era, Indonesia is currently experiencing many challenges. The challenges consist of various sectors including early childhood education. The case that is widely discussed is the problem of technology and social development of children in dealing with this era. However, this study provides insight into authoritarian parenting with the development of children's movements.

Motor development is one aspect of motor development that is very important for early childhood [2]. Motor development of children is inseparable from the opportunities given to develop the child's ability to move. Movement of children from birth to adulthood is a skill that can be used as a reference for motor development [3]. The movements performed require strength and function of the muscles to move. The motor movements of the child are able to move their arms and legs as a balance of strength in coordination and exercise courage [4].

Motor skills use large body muscles that include the functions of the motion apparatus such as sitting up straight, walking, kicking, and throwing a ball [5]. The gross motor skills of a child depend on the hardness and strength of the muscles. Motor skills are developed by children when they actively carry out repetition of motor skills that have been done so that they develop into new actions that are more complex [6]. Motor development depends on the frequency of motion being trained [7], so the child will experience increased motor skills. This development occurs if the child is given a big enough opportunity to perform physical activity in the form of movements that involve the whole body. Children have different motor skill according to their level of maturity [8]. The development of movements equipment for children aged 4-5 years, namely: walking, running, jumping.

Parents have different ways of providing space for children's movements. One of them is through the care given by parents. Parenting is a way for parents to establish interpersonal relationships with children based on giving attention or affection [9]. However, parents can provide direct control by guiding, supervising children and giving responsibility is a way for parents to provide care for children. Parenting that is run by parents is also obtained from previous experience. This upbringing has been carried over from generation to generation. However, each parent chooses a different way to apply the pattern of care given to their children.

Indonesian Child Protection Commission research explained that the results of a 2015 survey conducted in North Sumatra, South Sumatra, Banten, West Java, Central Java, East Java, West Nusa Tenggara, Sekatan Kalimantan, and South Sulawesi with a sample of 800 respondents Indonesian families (father, mother, and child) as many as $66.4 \%$ fathers and $71 \%$ of mothers only copied the parenting patterns of their parents. It was found that the quality of education and knowledge of parents related to parenting is still weak, because only $27.9 \%$ of fathers and $36.9 \%$ of mothers seek information on caring 
for and managing child care before marriage and only $38.9 \%$ of fathers and $56,2 \%$ of mothers seek information on caring for and managing their children's care after marriage. Direct parental involvement in the child parenting process is also still low, namely $26.2 \%$ of fathers and $25.8 \%$ of mothers said the parenting process was not assisted and was not transferred to others [10].

The quantity and quality of parent and child communication time is also still very minimal. In terms of quantity, the average time to communicate with children is only 1 hour per day, which is $47.1 \%$ for fathers and $40.6 \%$ for mothers. The habit of parents accompanying children in choosing games is good enough, namely $74.1 \%$ of fathers and $76.6 \%$ of mothers said accompanying children in choosing games according to their growth and development. Children's access to media needs to get supervision from parents, which is $56.5 \%$ of fathers and $55.8 \%$ of mothers provide mobile and smartphone facilities that have internet network, but $44.4 \%$ of fathers and $42.8 \%$ of mothers say they do not supervision and assistance to children in accessing media [10].

In line with the results of the data held by Indonesian Child Protection Commission, related to the relationship between parenting and children's motor development. Parenting have an indirect relationship that is higher than the direct relationship related to early childhood gross motor development, indirect relationships are obtained from information about the gross motor development of children by teachers and the means of play for motor development child.

Parenting is a way for parents to give love, a form of application given by parents to children to guide and influence, forms of effort given by parents to children in fostering and guiding body or soul, giving influence by parents to children related to attitudes and nature. Parenting consists of several types, namely authoritarian parenting, permissive parenting, and democratic parenting.

Parenting in this study is authoritarian parenting. Authoritarianism reflects the attitude of parents who are hard, parents provide absolute standards that must be obeyed and implemented, the provision of punishment both physical or verbal [11]. Authoritarian parenting puts pressure on children because all children's behavior is controlled by parents. The rules that apply apply based on the decision of the parents as a whole without any opinion given by the child.

Authoritarian parenting usually applies to families that have a fairly high level of discipline [12] Expectations and wishes of parents who are too high to be a necessity that must be done by children. Children of authoritarian parents make children shy, full of fear, withdrawn, at risk of being affected by depression, difficult to make decisions, and tend to be difficult to be independent. Punishment given to parents by hitting, screaming and screaming makes this a bad example to children. Not infrequently parents use violence in giving care to children.

The impact of authoritarian parenting will result in a child who is timid, quiet, introverted, unable to initiate, likes to oppose, likes to violate norms, has a weak personality, is anxious, and tends to withdraw from his social environment. However, authoritarian parenting has other distinct effects. This research aims to explain survey data on motor development with authoritarian parenting. Based on research data, it can be seen that children's motor development in the digital era with authoritarian parents.

\section{METHOD}

The design in this study uses survey which is a research design in which measurements and observations are carried out in a stimulant at one time [13]. The survey results allow researchers to examine the relationships between variables and draw conclusions from these relationships.

This study takes research objectives based on location and research criteria. Criteria in this study, namely kindergarten located in Central Surabaya which is divided into four districts, kindergarten with a minimum of $\mathrm{C}$ accreditation, using all children in the class as a sample, kindergarten A children aged 4-5 years totaling 128 children, carried out in Genteng District, Bubutan, Simokerto, and Tegalsari, kindergartens who gave research permission, children who were raised by biological parents and not guardians, parents who were willing to fill out questionnaires, children with motor development abilities (zig zag, jumping, walking backwards, and run).

Data collection techniques in this study used observation techniques and documentation techniques. The observation technique in this study used participant observation, in which the researcher was directly involved in observing the development of children's motor development. This form of observation is structured observation using research instruments that have been tested for validity and reliability.

Questionnaire technique in this study will be filled out online by parents of kindergarten A children at each school which is used as a place of research in Central Surabaya through the Google form. The contents of the questionnaire were about parenting provided by parents related to the motor development children aged 4-5 years.

This technique is used to document all activities in research in the form of photographs, assessment sheets, or videos. In a study conducted on kindergarten A children in Central Surabaya regarding the relationship of parenting with the motor development in the form observations and other supporting photographs.

\section{RESULT AND DISCUSSION}

The targets of this study are children of group A in Central Surabaya, which is divided into five kindergartens in four subdistricts, namely Aratisari kindergarten in Simokerto sub-district, Kartini kindergarten in Genteng sub-district, Tunas Adipura kindergarten in Tegalsari subdistrict, Tribina kindergarten and Tunas Demak kindergarten in Bubutan sub-district. The sources of this study were 128 children to see the development of motor and online questionnaire filling by parents.

The target was chosen based on several inclusion criteria that had been designed. These criteria are, school accreditation, kindergarten location, children aged 4-5 
years, children raised by biological parents, children with motor development abilities (zigzag, jumping, walking backwards, and running). Observations were made when the child was asked to do some motor development while playing, that is doing zig-zag walking, jumping, walking backwards, and running. The results obtained from the observation of the development of motor are as follows (Table 1).

Table 1

Scores Motor Development

\begin{tabular}{|l|l|l|l|l|}
\hline \multirow{2}{*}{ Location } & \multicolumn{4}{|c|}{ Scores } \\
\cline { 2 - 5 } & $\begin{array}{c}\text { Zig- } \\
\text { Zag }\end{array}$ & Run & Jumping & $\begin{array}{c}\text { Walking } \\
\text { backward }\end{array}$ \\
\hline TK Aratisari & 3,73 & 4,00 & 3,65 & 4,00 \\
\hline $\begin{array}{l}\text { TK Tunas } \\
\text { Adipura }\end{array}$ & 3,80 & 4,00 & 3,60 & 4,00 \\
\hline TK Kartini & 3,69 & 4,00 & 3,85 & 3,62 \\
\hline TK Tribina & 3,75 & 3,85 & 3,45 & 3,80 \\
\hline $\begin{array}{l}\text { TK Tunas } \\
\text { Demak }\end{array}$ & 4,00 & 4,00 & 3,87 & 3,73 \\
\hline
\end{tabular}

The results obtained from the motor development table, namely for group A children in Kindergarten Aratisari obtained the average number of scores for zigzagging is 3.73. Running obtained the average score is 4.00. Jumping obtained an average score of 3.65. Walking back obtained an average of 4.00. Group A at Tunas Adipura Kindergarten obtained the average number of scores for zigzagging walking was 3.80. Running obtained the average score is 4.00. Jumping obtained an average score of 3.60. Walking back obtained an average of 4.00 .

Group A in TK Kartini obtained an average number of scores to walk zigzagging was 3.69. Running obtained the average score is 4.00. Jumping obtained an average score of 3.85. Walking back obtained an average of 3.62. Group A in TK Tribina obtained an average number of scores for zigzagging walking is 3.75. Running obtained the average score is 3.85 . Jumping obtained an average score of 3.45 . Walking back obtained an average of 3.80 .

Group A in Tunas Demak Kindergarten obtained an average number of scores for zigzag walking was 4.00 . Running obtained the average score is 4.00. Jumping obtained an average score of 3.87. Walking back obtained an average of 3.73. Based on observations of the development of motor in each TK in each of these districts, the average score was above 3.81. So, it can be stated that the ability of motor development of kindergarten children A in Central Surabaya is included in the very well-developed category. The role of parenting on motor development has a very important influence. Survey data show that, in the era of the industrial revolution children with authoritarian parenting did not experience the effects of motor development. The impact of social development experienced by children with authoritarian parenting, but does not have an impact on motor skills.

\section{CONCLUSION}

The results showed that parents in Central Surabaya who adopted an authoritarian parenting had the difference in results in the locomotor development of children. The survey results show that the development of children's movements for the ability to walk score is 3.7 ; running score is 3.97 ; jumping score is 3.68 ; and walking backward score is 3.83 . From these results it shows the difference between a single developmental motion, there is no dominant or worse.

\section{REFERENCES}

[1] D. S. Yildirim, M. Bilge, and E. Caglar, "Effects of a training program based on longitudinal training of athlete development (ltad) approach on gross motor skills among 6-8 years old children," Eur. J. Phys. Educ. Sport Sci., vol. 0, no. 0, Jan. 2019.

[2] M. M. McClelland and C. E. Cameron, "Developing together: The role of executive function and motor skills in children's early academic lives," Early Child. Res. Q., vol. 46, pp. 142-151, Jan. 2019.

[3] V. Mancini, D. Rigoli, L. Roberts, and J. Piek, "Motor skills and internalizing problems throughout development: An integrative research review and update of the environmental stress hypothesis research," Res. Dev. Disabil., vol. 84, pp. 96-111, Jan. 2019.

[4] K. E. Adolph and J. E. Hoch, "Motor Development: Embodied, Embedded, Enculturated, and Enabling," Annu. Rev. Psychol., vol. 70, no. 1, pp. 141-164, Jan. 2019.

[5] N. Marlow, E. M. Hennessy, M. A. Bracewell, and D. Wolke, "Motor and Executive Function at 6 Years of Age After Extremely Preterm Birth," Pediatrics, vol. 120, no. 4, pp. 793-804, Oct. 2007.

[6] C. Bedard, E. Bremer, W. Campbell, and J. Cairney, "Evaluation of a Direct-Instruction Intervention to Improve Movement and Preliteracy Skills among Young Children: A Within-Subject Repeated-Measures Design," Front. Pediatr., vol. 5, Jan. 2018.

[7] C.-C. Kao et al., "Effect of interactive cognitive motor training on gait and balance among older adults: A randomized controlled trial," Int. J. Nurs. Stud., vol. 82, pp. 121-128, Jun. 2018.

[8] F. Kaneko and H. Okamura, "Study on the Social Maturity, Self-Perception, and Associated Factors, Including Motor Coordination, of Children with Attention Deficit Hyperactivity Disorder," Phys. Occup. Ther. Pediatr., vol. 25, no. 4, pp. 45-58, Jan. 2006.

[9] M. G. Lo Cricchio, A. Lo Coco, C. S. L. Cheah, and F. Liga, "The Good Parent: Southern Italian Mothers' Conceptualization of Good Parenting and Parent-Child Relationships," J. Fam. Issues, vol. 40, no. 12, pp. 1583 1603, Aug. 2019.

[10] R. Pranawati, "Komisi Perlindungan Anak Indonesia (KPAI) Riset Kebijakan dan Survei Nasional Kualitas Pengasuhan Anak Di Daerah,” Jakarta, 2015.

[11] E. J. Calzada, A. Sales, and J. L. O'Gara, "Maternal depression and acculturative stress impacts on Mexicanorigin children through authoritarian parenting," J. Appl. Dev. Psychol., vol. 63, pp. 65-75, Jul. 2019.

[12] P. P. S. Yadav and R. Chandola, "Authoritarian Parenting Style and Its Effect On Self-Esteem And Coping Strategies Of 21 Year Old Girl," Glob. J. Res. Anal., vol. 8, no. 3, Aug. 2019.

[13] J. E. Bartlett, J. W. Kotrlik, and C. C. Higgins, "Organizational Research: Determining Organizational Research: Determining Appropriate Sample Size in Survey Research Appropriate Sample Size in Survey Research," 2001. 